\title{
Phoretic mites (Rhinoseius spp.) in Apodiformes from Cerrado and Pantanal Biomes in midwestern Brazil
}

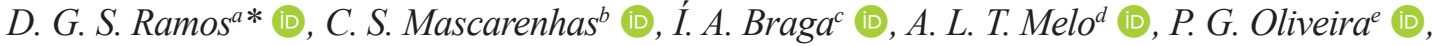 \\ K. C. Saturninof (D), A. L. Sinkoc ${ }^{\text {(D) D. D. Aguiarg (D) and R. C. Pacheco }}{ }^{\text {(D) }}$ \\ ${ }^{a}$ Unidade Acadêmica Especial de Ciências Veterinárias, Universidade Federal de Goiás - UFG, R. Riachuelo, 1530, \\ Setor Samuel Graham, CEP 75804-020, Jataí, GO, Brasil
}

bPrograma de Pós-graduação em Parasitologia, Departamento de Microbiologia e Parasitologia, Universidade Federal de Pelotas - UFPEL, Campus Capão do Leão, CEP 96010-900, Pelotas, RS, Brasil

'Departamento de Ciências Agrárias, Centro Universitário de Mineiros - UNIFIMES, Rua 22, s/n, Setor Aeroporto, CEP 75830-000, Mineiros, GO, Brasil

dPrograma de Pós-graduação em Biociência Animal, Universidade Cuiabá - UNIC, Av. Beira Rio, 3048, Jardim Europa, CEP 78065-900, Cuiabá, MT, Brasil

'Programa de Pós-graduação em Biociência Animal, Unidade Acadêmica Especial de Ciências Veterinárias, Universidade Federal de Goiás - UFG, R. Riachuelo, 1530, Setor Samuel Graham, CEP 75804-020, Jataí, GO, Brasil

fUnidade Acadêmica Especial de Ciências Veterinárias, Universidade Federal de Goiás - UFG, R. Riachuelo, 1530, Setor Samuel Graham, CEP 75804-020, Jataí, GO, Brasil

gFaculdade de Medicina Veterinária, Universidade Federal de Mato Grosso - UFMT, Av. Fernando Corrêa da Costa, 2367, Boa Esperança, CEP 78060-900, Cuiabá, MT, Brasil

*e-mail: dgramos_vet@hotmail.com

Received: March 5, 2019 - Accepted: July 16, 2019 - Distributed: November 30, 2020

(With 1 figure)

\begin{abstract}
Nasal mites are commonly found in hummingbirds (Apodiformes). In most cases, endoparasitic mites were reported to parasitize the respiratory system, particularly the anterior nasal chambers, larynx, trachea, lungs, and the air and conjunctival sacs. However, some mites are only carried by hummingbirds, because flowers serving as a nutrient source for these small mites, such as for Apodiformes, a tropical nectar-feeding in their natural habitat. From August 2012 to May 2014, humminbirds were captured using mist nets, and examined for the presence of nasal mites (identified according to specific keys) in the Pantanal, and Cerrado biomes, from the Mato Grosso state, midwestern Brazil. Overall, 76 Apodiform specimens, from the Trochilidae family were captured, and 20 female nasal mites, identified as being from the Rhinoseius genus, were collected from eight hosts (10.5\%), of the following species: Amazilia fimbriata, Amazilia versicolor, Eupetonema macroura, and Thalurania furcata. The Rhinoseius spp. has been reported on, in many ecosystems in the Americas, including Brazil, however, this is the first report on Apodiformes from the Pantanal biome. Phoretic mites are not responsible for direct damage to the population of Apodiformes, as they are not pathogenic. However, they compete for food with hummingbirds and decrease the quantity of food available in the environment. They also affect the reproductive dynamics of plants, feed on pollen, and interfere with the intricacies of the biodiversity where they live.
\end{abstract}

Keywords: hummingbird, nasal mites, Trochilidae, phoresy.

\section{Ácaros Foréticos (Rhinoseius spp.) em Apodiformes dos Biomas Cerrado e Pantanal no Centro-Oeste do Brasil}

\section{Resumo}

Os ácaros nasais são comumente encontrados em beija-flores (Apodiformes). Na maioria dos casos, os ácaros foram relatados como endoparasitas, parasitando o sistema respiratório, particularmente as câmaras nasais anteriores, a laringe, a traqueia, os pulmões e os sacos aéreos e conjuntivais. No entanto, alguns ácaros são transportados apenas por beija-flores, pois flores servem como fonte de nutrientes para esses pequenos ácaros, assim como para Apodiformes tropicais alimentados de néctar em seu habitat natural. De agosto de 2012 a maio de 2014, beija-flores foram capturadas com redes de neblina e examinadas quanto à presença de ácaros nasais (identificados de acordo com chaves específicas) nos biomas Pantanal e Cerrado, no estado do Mato Grosso, Centro-Oeste do Brasil. No total, 76 exemplares Apodiformes da família Trochilidae foram capturados e 20 fêmeas de ácaros nasais, identificados 
como pertencentes ao gênero Rhinoseius, foram coletados de oito hospedeiros (10,5\%), das seguintes espécies: Amazilia fimbriata, Amazilia versicolor, Eupetonema macroura e Thalurania furcata. Rhinoseius spp. foi relatado em muitos ecossistemas nas Américas, incluindo o Brasil, no entanto, este é o primeiro relato em Apodiformes do bioma Pantanal. Os ácaros foréticos não são responsáveis por danos diretos à população de Apodiformes, pois não são patogênicos. No entanto, eles competem por comida com beija-flores e diminuem a quantidade de comida disponível no ambiente. Eles também afetam a dinâmica reprodutiva das plantas, se alimentam de pólen e interferem nas interações da biodiversidade em que vivem.

Palavras-chave: beija-flor, ácaros nasais, Trochilidae, foresia.

\section{Introduction}

Nasal mites have been reported in several hummingbird species (Apodiformes) from Latin America (Baker and Yunker, 1964; Dusbabek and Cerny, 1970; Hunter, 1972; Fain et al., 1977; Hyland et al., 1978; Colwell and Naeem, 1979; Fain and Hyland, 1980; Micherdzinski and Lukoschus, 1980; O'Connor et al., 1991; Ohmer et al., 1991; Naskrecki and Colwell, 1998; Dusbabek et al., 2007; López-Orozco and Cañon-Franco, 2013). The reports include a description of infestation of many Mesostigmata mites species, in general, in hummingbirds from Brazil and birds also (De-Castro, 1948; Pereira and De-Castro, 1949; Amaral, 1968; Amaral and Rebouças, 1974; Mascarenhas et al., 2011; Bernardon et al., 2013; Mendes et al., 2014).

In most reported cases, endoparasitic mites that inhabit the respiratory system of Apodiformes parasitize the anterior nasal chambers, larynx, trachea, lungs, and the air and conjunctival sacs (Amaral and Rebouças, 1974). However, in some cases the mites found are only carried, and dispersed by the Apodiformes, with flowers serving as a source of nutrients for these hosts in their natural habitat and for the mites (Proctor and Owens, 2000). Thus, the present study aimed to describe the occurrence of nasal mites in Apodiformes from the Pantanal and Cerrado biomes of the Mato Grosso state, midwestern Brazil.

\section{Material and Methods}

From August 2012 to May 2014, hummingbirds were captured as primary samples for another project on rickettsial infection spread from ticks of birds (Ramos et al., 2015).
These Apodiformes were examined for the presence of ectoparasites that included nasal mites in two different biomes in the Mato Grosso state, including Pantanal and Cerrado biomes in the municipalities of Poconé and Chapada dos Guimarães. In each area, 10 mist nets ( $10 \mathrm{~m}$ long, $3 \mathrm{~m}$ high with $1 \mathrm{~cm}$ mesh holes) were opened on five days between 6:00 a.m. and 11:00 a.m., resulting in 3500 network hours throughout the study, and captured hummingbirds were identified according to Ridgely and Tudor $(1989,1994)$, and Sigrist (2006). Mites were collected directly from the nasal fossae, with the aid of brush and forceps, preserved in absolute isopropanol, and then brought to the laboratory. Samples were processed according to Henderson (2001), and were morphologically identified according to the keys proposed by O'Connor et al. (1991) and Naskrecki and Colwell (1998).

\section{Results}

Among the 76 Apodiformes from the Trochilidae family captured, there was a total of 12 different species. Table 1 provides a list of all the captured Apodiform species, and the results of infestation by nasal mites, grouped according to biomes. Overall, 20 female mites were collected and identified as being from the Rhinoseius genus (Rhinoseius spp.), as shown in figure 1.

\section{Discussion}

The term "hummingbird flower mite", although little known, is used to define the relationship that occurs with Apodiformes (hummingbird), flowers and mites of

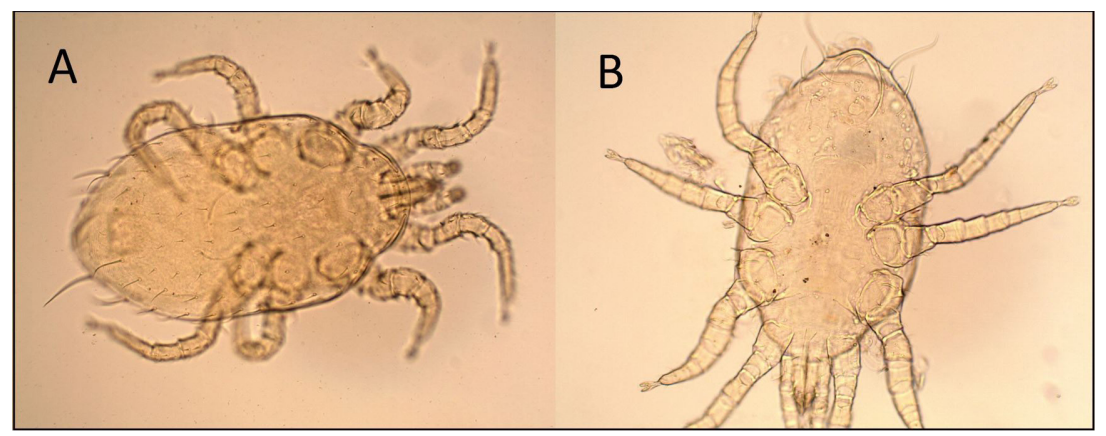

Figure 1. Nasal mites collected in hummingbird (Apodiformes) from Pantanal and Cerrado biomes of Mato Grosso state, midwestern Brazil, from August 2012 to May 2014. (A) Rhinoseius spp. female collected from nasal fossae of Amazilia versicolor; (B) Rhinoseius spp. female collected from nasal fossae of Thalurania furcata. 
Table 1. Apodiformes (Trochilidae) from Cerrado and Pantanal biomes of the Mato Grosso state between 2012 and 2014 , quantified by species and biomes, and Rhinoseius spp. occurrence and abundance in these hummingbirds.

\begin{tabular}{|c|c|c|c|c|}
\hline Biome & Host & $\begin{array}{c}\text { Captured } \\
\text { Hummingbirds }\end{array}$ & $\begin{array}{c}\text { Positive for } \\
\text { Rhinoseius spp. }\end{array}$ & $\begin{array}{c}\text { Abundance of } \\
\text { Rhinoseius spp. } \\
\text { (female) collected }\end{array}$ \\
\hline \multirow[t]{10}{*}{ Cerrado } & Amazilla fimbriata & 10 & 2 & 6 \\
\hline & Amazilla versicolor & 1 & 1 & 2 \\
\hline & Chlorostilbon lucidus & 3 & - & - \\
\hline & Chrysolampis mosquitos & 9 & - & - \\
\hline & Colibri serrirostris & 2 & - & - \\
\hline & Eupetomena macroura & 2 & 1 & 3 \\
\hline & Hylocharis cyanus & 7 & - & - \\
\hline & Phaethornis nattereri & 1 & - & - \\
\hline & Phaethornis petrei & 2 & - & - \\
\hline & Thalurania furcata & 12 & 2 & 5 \\
\hline \multirow[t]{7}{*}{ Pantanal } & Amazilla fimbriata & 12 & 1 & 3 \\
\hline & Amazilla versicolor & 8 & - & - \\
\hline & Anthracothorax nigricolis & 2 & - & - \\
\hline & Chrysolampis mosquitos & 1 & - & - \\
\hline & Eupetomena macroura & 1 & - & - \\
\hline & Phaetornis ruber & 2 & - & - \\
\hline & Thalurania furcata & 1 & 1 & 1 \\
\hline TOTAL & & 76 & 8 & 20 \\
\hline
\end{tabular}

the family Ascidae (Mesostigmata) (López-Orozco and Cañon-Franco, 2013). These mites have been described as parasitizing to Apodiformes and Passeriformes, and are identified into approximately 22 genera, and 60 species (Naskrecki and Colwell, 1998), with the most common genera being: Lasioseius Berlese, Proctolaelaps Berlese, Rhinoseius Baker and Yunker, and Tropicoseius Baker and Yunker (O'Connor et al., 1991; Proctor and Owens, 2000; Dusbabek et al., 2007).

According to MacChioni (2007) phoresy is the interaction between one species of animal that passively attaches to another species of animal, the relationship ranges from a state of quiescence, to life cycle synchronization. If the relationship involves hummingbirds, plants and mites, then the plants act as habitats, while the hummingbirds only act as carriers and dispersers for the mites, parasitism does not occur as part of the mites biological life cycle (Hunter, 1972; Guerra et al., 2010). Following this model, Rhinoseius spp. feed on pollen during the nymph stage, and nectar in the adult stage (Hunter, 1972), this food habit decreases the amount of food available in the environment for nectarivorous species, and also causes a negative impact on the reproductive dispersion of the plants carried by these hummingbirds (Heyneman et al., 1991; Lara and Ornelas, 2001; Velázquez and Ornelas, 2010). Thus, although phoresy is an interspecific relationship classified as commensal, it does have a negative impact, because there is less food available for the Apodiform species, and reduced reproduction in plants (Colwell, 1995).

There are reports of the Rhinoseius spp. being found in hummingbirds from Colombia (Fain and Hyland, 1980;
Ohmer et al., 1991; López-Orozco and Cañon-Franco, 2013), Costa Rica (Hunter, 1972), Ecuador (Micherdzinski and Lukoschus, 1980), United States of America (Colwell and Naeem, 1979), Mexico (Hyland et al., 1978), Panama (Fain et al., 1977), Trinidad and Tobago (Fain et al.,1977), Venezuela (Fain et al., 1977; Micherdzinski and Lukoschus, 1980), and also in Brazil (Fain et al., 1977; Flechtmann and Johnston, 1978). However, this is the first report of Rhinoseius spp. being detected in Apodiformes from the Pantanal biome, thus amplifying the knowledge of the distribution of phoretic mites in hummingbirds.

The knowledge about phoretic mites is important, mainly for the development and conservation of biodiversity. It is important to consider that phoretic mites can cause indirect damage to the Apodiform population, and also to the reproductive dynamics of plants, and their ecosystems, in which these mites are inserted.

\section{References}

AMARAL, V., 1968. Notas sobre ácaros nasais com a descrição de duas novas espécies: Ptilonyssus zeferinoi $\mathrm{n}$. sp. e Sternostoma clementei n. sp. (Acarina: Rhinonyssidae). Lista das espécies descritas no Brasil e seus hospedeiros. Arquivos do Instituto Biológico, vol. 35, pp. 107-126.

AMARAL, V. and REBOUÇAS, M.M., 1974. Notas sobre ácaros rinonissídeos de aves brasileiras (Mesostigmata - Rhinonyssidae). O Biológico, vol. 40, pp. 52-56.

BAKER, E.W. and YUNKER, C.E., 1964. New Blattisociid mites (Acarina: Mesostigmata) recovered from neotropical flowers and hummingbirds' nares. Annals of the Entomological 
Society of America, vol. 57, no. 1, pp. 103-126. http://dx.doi. org/10.1093/aesa/57.1.103.

BERNARDON, F.F., MULLER, G. and MASCARENHAS, C.S., 2013. Rhinonyssidae (Acari: Gamasida) in Ardeidae (Aves: Pelicaniformes) in Brazil. Brazilian Journal of Biology $=$ Revista Brasileira de Biologia, vol. 73, no. 3, pp. 673-674. http://dx.doi. org/10.1590/S1519-69842013000300029. PMid:24212712.

COLWELL, R.K. and NAEEM, S., 1979. The first known species of hummingbird flower mite North of Mexico: Rhinoseius epoecus n. sp. (Mesostigmata: Ascidae). Annals of the Entomological Society of America, vol. 72, no. 4, pp. 485-491. http://dx.doi. org/10.1093/aesa/72.4.485.

COLWELL, R.K., 1995. Effects of nectar consumption by the hummingbird flower mite Proctolealaps kirmse on nectar availability in Hamelia patens. Biotropica, vol. 27, no. 2, pp. 206-217. http://dx.doi.org/10.2307/2388996.

DE-CASTRO, M.P., 1948. Reestruturação genérica de família Rhinonyssidae Vitzthum, 1935 (Acari: Mesostigmata: Gamasides) e descrição de algumas espécies novas. Arquivos do Instituto Biológico, vol. 18, pp. 253-284.

DUSBÁBEK, F. and CERNY, V., 1970. The nasal mites of Cuban birds. I. Ascidae, Ereynetidae, Trombiculidae (Acarina). Acarologia, vol. 12, no. 2, pp. 269-281. PMid:5530497.

DUSBÄBEK, F., LITERAK, I., CAPEK, M. and HAVLICEK, M., 2007. Ascid mites (Acari: Mesostigmata: Ascidae) from Costa Rican hummingbirds (Aves: Trochilidae), with description of three new species and a key to the Proctolaelaps belemensis species group. Zootaxa, vol. 1484, no. 1, pp. 51-67. http://dx.doi. org/10.11646/zootaxa.1484.1.3.

FAIN, A. and HYLAND, K.E., 1980. New species of the genus Rhinoseius Baker and Yunker, 1964 (Mesostigmata: Ascidae) phoretic on Colombian hummingbirds. International Journal of Acarology, vol. 6, no. 1, pp. 15-24. http://dx.doi. org/10.1080/01647958008683187.

FAIN, A., HYLAND, K.E. and AITKEN, T.H.G., 1977. Nouveaux acariens Ascidae (Mesostigmates) phorétiques dans les fosses nasales de colibris: note préliminaire. Bulletin et Annales de la Société Royale Belge d'Entomologie, vol. 113, pp. 184-186.

FLECHTMANN, C.H.W. and JOHNSTON, D.E., 1978. Rediscovery and redescription of Rhinoseius braziliensis (Acari: ascidae). Revista Brasileira de Entomologia, vol. 22, no. 3-4, pp. 165-166.

GUERRA, T.J., ROMERO, G.Q., COSTA, J.C., LOFEGO, A.C. and BENSON, W.W., 2010. Phoretic dispersal on bumblebees by bromeliad flower mites (Mesostigmata, Melicharidae). Insectes Sociaux, vol. 59, no. 1, pp. 11-16. http://dx.doi.org/10.1007/ s00040-010-0091-4.

HENDERSON, R.C., 2001. Technique for positional slidemounting of Acari. Systematic and Applied Acarology, vol. 7, no. 1, pp. 1-4. http://dx.doi.org/10.11158/saasp.7.1.1.

HEYNEMAN, A.J., COLWELL, R.K., NAEEM, S., DOBKIN, D.S. and HALLET, B., 1991. Host plant discrimination: experiments with hummingbird flower mites. In: P.W. PRICE, T.M. LEWINSOHN, G.W. FERNANDES and W.W. BENSON, eds. Plant-animal interactions: evolutionary ecology in tropical and temperate regions. New York: John Wiley \& Sons, pp. 455-485.

HUNTER, P.E., 1972. New Rhinoseius species (Mesostigmata: Ascidae) from Costa Rican hummingbirds. Journal of the Georgia Entomological Society, vol. 7, no. 1, pp. 26-35.
HYLAND, K.E., FAIN, A. and MOORHOUSE, A.S., 1978. Ascidae associated with the nasal cavities of Mexican birds (Acarina: mesostigmata). Journal of the New York Entomological Society, vol. 86, no. 3, pp. 260-267.

LARA, C. and ORNELAS, J.F., 2001. Nectar "theft" by hummingbird flower mites and its consequences for seed set in Moussonia deppeana. Functional Ecology, vol. 15, no. 1, pp. 78-84. http://dx.doi.org/10.1046/j.1365-2435.2001.00486.x.

LÓPEZ-OROZCO, N. and CAÑON-FRANCO, W.A., 2013. Phoretic mites identified on andean hummingbirds (Trochilidae) of Caldas, Colombia. Revista Brasileira de Parasitologia Veterinária, vol. 22, no. 2, pp. 194-200. http://dx.doi.org/10.1590/S198429612013000200039 . PMid:23856724.

MACCHIONI, F., 2007. Importance of phoresy in the transmission of Acarina. Parassitologia, vol. 49, no. 1-2, pp. 17-22. PMid:18412039.

MASCARENHAS, C.S., COIMBRA, M.A.A., MULLER, G. and BRUM, J.G.W., 2011. Nasal Mites (Gamasida: Rhinonyssidae) of Paroaria coronata (Miller) (Passeriformes: Emberezidae). Neotropical Entomology, vol. 40, no. 4, pp. 507-508. http:// dx.doi.org/10.1590/S1519-566X2011000400016. PMid:21952970.

MENDES, M.M., MASCARENHAS, C.S., SINKOC, A.L. and MULLER, G., 2014. Nasal mites of Tyrannidae (Aves) in Brazil. Brazilian Journal of Biology = Revista Brasileira de Biologia, vol. 74, no. 2, pp. 480-482. http://dx.doi.org/10.1590/15196984.12912. PMid:25166334.

MICHERDZINSKI, W. and LUKOSCHUS, F.S., 1980. Rhinoseius rafinskii, a new species from Ecuador and Venezuela (Acari, Gamasina, Ascidae). Zoölogische Mededeelingen, vol. 55 , no. 6 , pp. 65-79.

NASKRECKI, P. and COLWELL, R.K., 1998. Systematics and host plant affiliations of hummingbird flower mites of the Genera Tropicoseius Bayer and Yunker and Rhinoseius Baker and Yunker (Acari: Mesostigmata: Ascidae). Maryland: Entomological Society of America.

O'CONNOR, B.M., COLWELL, R.K. and NAEEM, S., 1991. Flower mites of Trinidad II. The genus Proctolaelaps (Acari: ascidae). The Great Basin Naturalist, vol. 51, no. 4, pp. 348-376.

OHMER, C., FAIN, A. and SCHUCHMANN, K.L., 1991. New ascid mites of the genera Rhinoseius Baker and Yunker, 1964, and Lasioseius Berlese, 1923 (Acari: Gamasida: Ascidae) associated with hummingbirds or hummingbird-pollinated flowers in Southwestern Colombia. Journal of Natural History, vol. 25, no. 2, pp. 481-497. http://dx.doi.org/10.1080/00222939100770301.

PEREIRA, C. and DE-CASTRO, M.P., 1949. Revisão da subfamília Ptilonyssinae Castro, 1948 (Acari: Mesostigmata: Rhinonyssidae) com a descrição de algumas espécies novas. Arquivos do Instituto Biológico, vol. 19, pp. 218-235.

PROCTOR, H. and OWENS, I., 2000. Mites and birds: diversity parasitism and coevolution. Trends in Ecology \& Evolution, vol. 15, no. 9, pp. 358-364. http://dx.doi.org/10.1016/S01695347(00)01924-8. PMid:10931667.

RAMOS, D.G.S., MELO, A.L.T., MARTins, T.F., ALVES, A.S., PACHECO, T.A., PINTO, L.B., PINHO, J.B., LABRUNA, M.B., DUTRA, V., AGUIAR, D.M. and PACHECO, R.C., 2015. Rickettsial infection in ticks from wild birds from Cerrado and the Pantanal region of Mato Grosso, midwestern Brazil. Ticks and Tick-Borne Diseases, 
vol. 6, no. 6, pp. 836-842. http://dx.doi.org/10.1016/j. ttbdis.2015.07.013. PMid:26232933.

RIDGELY, R.S. and TUDOR, G., 1989. The birds of South America: the oscine passerines. Oxford: Oxford University Press, vol. 1.

RIDGELY, R.S. and TUDOR, G., 1994. The birds of South America: the suboscine passerines. Oxford: Oxford University Press, vol. 2.
SIGRIST, T., 2006. Aves do Brasil: uma visão artística. 2. ed. São Paulo: Fosfértil, 672 p.

VELÁZQUEZ, T. and ORNELAS, J.F., 2010. Pollen consumption by flower mites in three hummingbird-pollinated plant species. Experimental \& Applied Acarology, vol. 50, no. 2, pp. 97-105. http://dx.doi.org/10.1007/s10493-009-9309-4. PMid:19763848. 